\title{
AN ANALYSES OF GOAL 14 (LIFE BELOW WATER/TARGETS) OF THE UNITED NATIONS' SUSTAINABLE DEVELOPMENT GOALS 2019 TO THE DEVELOPMENT OF MARINE/ BLUE ECONOMY TOWARDS THE ATTAINMENT OF THE SAID GOAL, EXISTING LEGAL FRAMEWORK AND POTENTIAL THREATS IN NIGERIA AND THE GLOBAL ENVIRONMENT
}

\author{
DR. SYLVANUS ABILA, Ph.D*1 $\quad$ O.J OBASOHAN** $\quad$ OPUTA, TARIYE ANDREW***
}

\begin{abstract}
:
The paper is an analyses of goal 14 (life below water/targets) of the United Nations' sustainable development goals 2019 to the development of marine/blue economy towards the attainment of the said goal, existing legal framework and potential threats in Nigeria and the global environment. The threats examined in this paper include: the threat of ocean acidification, the threat of ocean dead zones, the threat of overfishing and the threat of ocean waste in the oceans. The paper adopts an admixture of the doctrinal, historical, comparative, the law and development and empirical approaches. The paper ends with a conclusion and a set of recommendations.

KEYWORDS: Analyses, Goal 14, life below Water, Targets, United Nations, Sustainable Development, Goals 2019, Development, Marine/Blue Economy, Attainment, Existing, Legal Framework, Potential, Threats, Nigeria, Global Environment.
\end{abstract}

DOI: $10.7176 / J L P G / 96-16$

Publication date: April $30^{\text {th }} 2020$

\section{Introduction:}

Goal 14 of the millennium development goals 2019 of the United Nations, essentially deals with the conservation and sustainability in the use of the oceans, seas and resources in the marine sector of the global economy. It is submitted that this goal is founded on the fact that, oceans, lakes, rivers, wetlands, excavated wells, rain water, ponds and coastal waters which provide the key natural resources including medicines, food, biofuels and other products. ${ }^{2}$ These provides are also known to contribute to the breakdown and process of removal of pollution and wastes generally and also contributes in the process of acting as buffers around the coastal ecosystems in reducing damages from arising from storms. Apart from ensuring the maintenance healthy coastal waters, rivers or oceans, life below water supports climate change mitigation and adaptation to a large extent. Coastal waters, oceans, and rivers are also known to provide tourist and recreation centre for humanity globally. It has also been rightly observed that the oceans, cover more than 70 per cent to 99 per cent of the surface of the planet and play key roles in supporting life on earth. ${ }^{3}$ As noted earlier, the life below water is, also the "most diverse and important ecosystem, contributing to global and regional elemental cycling, and regulating the climate. The oceans provide natural resources including food, materials, substances, and energy. [Marine Protected Areas are also known to] ......contribute to poverty reduction by increasing fish catches and income, and improving health. They also help improve gender equality, as women do much of the work at small-scale fisheries." 4

$1 *$ Dr. Sylvanus, Abila is a Senior Lecturer/Former Head of Department, Private and Property Law, Faculty of Law Niger Delta University, Wilberforce Island, Bayelsa State, Nigeria. The author can be reached on 08036712455 or by email: drabilasylvanus@gmail.com

** Obasohan, O.J. L.LM, BL, MPA, Lecturer, Benson Idahosa University, Benin City, Edo State, Nigeria. E-mail: jobasonhhan@,biu.edu.eng, omi4obasohan@yahoo.com. Phone: 08038409537.

*** OPUTA, Tariye Andrew. (LL.M, BL, LL.B), Lecturer II, Institute of Foundation Studies, Federal University Otuoke. Bayelsa State. Email: oputata@fuotuoke.edu.ng and mytariye1@gmail.com

${ }^{2}$ https://www.un.org/sustainabledevelopment/wp-content/uploads/2018/09/14.pdf visited on the 22/04/2020. To find out more about Goal $\# 14$ and other Sustainable Development Goals visit: http://www.un.org/sustainabledevelopment

3 UNEP - UN Environment Programme: https: www.Unenvironment.org/explore-topics/sustainabledevelopment-goals/why-do-sustainable-development-goals-matters. To learn more about UN Environment's contributions to SDG 14.

4 http://www.unevironment.org/explore-topics/sustainable-development-goals/why-do-sustainable-development-goals- 
Furthermore, the marine environment is also home to a "stunning variety of beautiful creatures, ranging from single-celled organisms to the biggest animal ever to have live on the Earth-the blue whale. They are also home to coral reefs, one of the most diverse ecosystems on the planet".

It is important to note also that the "loss of marine and coastal habitats (e.g. corals, mangroves, sea-grasses and saltmarshes) exposes infrastructure and high-value agricultural land to storms, erosion and flooding. Around half of the world's corals have already been lost in the last 30 years and up to half the world's mangroves in the last 50 years". ${ }^{1}$

\section{The Targets of Goal 14 of the 2019 United Nations' Sustainable Development Goals and Global Environment. ${ }^{2}$}

The target of this goal essentially is connected to the environment with the additional following targets:

i. "Target 14.1: By 2025, prevent and significantly reduce marine pollution of all kinds, in particular from land-based activities, including marine debris and nutrient pollution. ${ }^{3}$

ii. Target 14.2: By 2020, sustainably manage and protect marine and coastal ecosystems to avoid significant adverse impacts, including by strengthening their resilience, and take action for their restoration in order to achieve healthy and productive oceans. ${ }^{4}$

iii. Target 14.3: Minimize and address the impacts of ocean acidification, including through enhanced scientific cooperation at all levels. ${ }^{5}$

iv. Target 14.4: By 2020, effectively regulate harvesting and end overfishing, illegal, unreported and unregulated fishing and destructive fishing practices and implement science-based management plans, in order to restore fish stocks in the shortest time feasible, at least to levels that can produce maximum sustainable yield as determined by their biological characteristics. ${ }^{6}$

v. Target 14.5: By 2020, conserve at least 10 per cent of coastal and marine areas, consistent with national and international law and based on the best available scientific information. ${ }^{7}$

vi. Target 14.6: By 2020, prohibit certain forms of fisheries subsidies which contribute to overcapacity and overfishing, eliminate subsidies that contribute to illegal, unreported and unregulated fishing and refrain from introducing new such subsidies, recognizing that appropriate and effective special and differential treatment for developing and least developed countries should be an integral part of the World Trade Organization fisheries subsidies negotiation. ${ }^{8}$

vii. Target 14.7: By 2030, increase the economic benefits to Small Island developing States and least developed countries from the sustainable use of marine resources, including through sustainable management of fisheries, aquaculture and tourism. ${ }^{9}$

viii. Target 14.a: Increase scientific knowledge, develop research capacity and transfer marine technology, taking into account the Intergovernmental Oceanographic Commission Criteria and Guidelines on the Transfer of Marine Technology, in order to improve ocean health and to enhance the contribution of marine biodiversity to the development of developing countries, in particular small island developing States and least developed countries. ${ }^{10}$

matter/goal-14. Visited last on the 22/04/2020. To learn more about UN Environment's contributions to SDG 14: (1). SDG Policy Brief on Ocean: Marine Pollution, (2). SDG Policy Brief on Global Biodiversity.

${ }^{1}$ Van Hooidonk, R., Maynard, J. A., Manzello, D. and Planes, S. 2013. Opposite latitudinal gradients in projected ocean acidification and bleaching impacts on coral reefs. Global Change Biology 20: 103-112, 14 Donato, D. C. et al. 2011. Mangroves among the most carbon-rich forests in the tropics. Nature Geoscience 4: 293.

2 http://www.unevironment.org/explore-topics/sustainable-development-goals/why-do-sustainable-development-goalsmatter/goal-14. Visited last on the 22/04/2020. To learn more about UN Environment's contributions to SDG 14: (1). SDG Policy Brief on Ocean: Marine Pollution, (2). SDG Policy Brief on Global Biodiversity.

${ }^{3}$ Ibid.

${ }^{4}$ Ibid.

${ }^{5}$ Ibid.

${ }^{6}$ Ibid.

${ }^{7}$ Ibid.

${ }^{8}$ Ibid.

${ }^{9}$ Ibid.

${ }^{10}$ Ibid. 
ix. $\quad$ Target 14.b: Provide access for small-scale artisanal fishers to marine resources and markets. ${ }^{1}$

x. Target 14.c: Enhance the conservation and sustainable use of oceans and their resources by implementing international law as reflected in UNCLOS, which provides the legal framework for the conservation and sustainable use of oceans and their resources, as recalled in paragraph 158 of The Future We Want".

\section{An overview of the Importance and Economy Potentials of Life below Water, the Marine/Blue Economy to} Sustainable Development in the Global Environment:

In examining the above overview it is important to note that flowing from the above available data, statistics, facts and figures of life below water ${ }^{2}$ it has now been firmly established that "increasing levels of debris in the world's seas and oceans is having a major and growing economic impact. The data, statistics, facts and figures show that: oceans cover three quarters of the Earth's surface and contain 97 per cent of the Earth's water, representing 99 per cent of the living space on the planet by volume. ${ }^{3}$ Furthermore, over three billion people are known to depend on marine and coastal biodiversity for their livelihoods. ${ }^{4}$ Globally, the market value of marine and coastal resources and industries is estimated at $\$ 3$ trillion per year or about 5 per cent of global GDP while oceans absorb about 30 per cent of carbon dioxide produced by humans, buffering the impacts of global warming. ${ }^{5}$ Furthermore, "oceans serve as the world's largest source of protein, with more than 3 billion people depending on the oceans as their primary source of protein while marine fisheries directly or indirectly employ over 200 million people." ${ }^{\prime \prime}$ The importance of water to the "survival of mankind, flora and fauna cannot be over emphasized. Thus, next to air, the most essential element to human life is water. The body cannot survive longer than some days without water. It is not only essential to every single cell and organ in the body, water significantly make up the constituents of all living things, and up to two-thirds of the weight of the human body".7

Though, water is a simple common fluid: it is considered as the "livewire of many human activities. It has many uses and unique attributes. The potential threats of pollution, extinction, scarcity and conflicts make it regulation by the law inevitable. For example, it can be used simultaneously by many users for agriculture, boating, navigation, hydroelectric power generation, fishing, etc. The right to water is therefore, a legal entitlement of a person, group of persons or a nation, to use water or even divert it to curtail wasteful use". ${ }^{8}$ Even though, the right to it is proprietary in nature, "yet holders do not own the water. The best they have is possessory right for use". 9 It is instructive to note that "water law, just like other natural resource laws, evolved from a number of principles. Its evolution was relatively uncoordinated and ad hoc. Recently, a more coordinated effort at making policies was widespread to protect this finite resource, anchored on specific set of rules aimed at fostering the holistic development of water resources in most jurisdictions globally and to effectively grapple with the challenges of the water subsector in the new millennium". ${ }^{10}$

\section{An overview of the Importance of Marine/Blue Economy in Relationship with Life below Water:}

The marine economy which is interchangeably used by most scholars as the "blue economy" is known to refer to the entirety of the marine-based economic development leading to the improvement of human wellbeing and social equity, while significantly reducing environmental risks and ecological scarcities. It is significant to note that between the $19^{\text {th }}$ to $20^{\text {th }}$ January, 2014, participants of the Blue Economy Summit adopted the Abu Dhabi

\footnotetext{
${ }^{1}$ Ibid.

https://www.un.org/sustainabledevelopment/oceans/ visited last on the 21/04/2020. See also http://www.undp.org/content/undp/en/home/sustainable-development-goals/goal-14-life-below-water.htm visited last on the $21 / 04 / 2020$

${ }^{3}$ Ibid.

${ }^{4}$ Ibid.

${ }^{5}$ Ibid.

${ }^{6}$ Ibid.

${ }^{7}$ Water Sector Governance in Africa, Vol. 2 Assessment Guidelines, 2010, Water Partnership Program (WPP) of the African Development Bank. Printing Finzi Usines Graphiques. September, 2010.

${ }^{8}$ California Environmental Protection Agency "Water rights process", See also Water and Sanitation Governance in Nigeria: Challenges and Prospects by Prof. Amari Omaka, President, Greenbelt Africa Initiative, http://greenbeltafricainitiative 1org.blogspot.com/Flat 6, $2^{\text {nd }}$ Floor, 14 Ojeawere Street Abakaliki. In a workshop organized by Rural Africa Health Water Sanitation Initiative (RAHWSI) on the $5^{\text {th }}$ Water, Heath and Sanitation Summit, at Pastoral Centre Abakaliki, Ebonyi State from $17-20^{\text {th }}$ Day of September, 2012.

${ }^{9}$ Ibid.

${ }^{10}$ Ibid.
} 
Declaration", which described the blue economy as: "Conserve and sustainably use the oceans, seas and marine resources for sustainable development". Furthermore, the Commonwealth Blue Economy Paper $(2016)^{2}$ pointed out that "the blue economy can maximize the economic value of the marine environment in a sustainable manner that preserves and protects the sea's resources and ecosystems". ${ }^{3}$ Deodat Maharaj, Deputy Secretary-General, Economic and Social Development who wrote the forward to the Commonwealth Blue Economy paper aforesaid, gave far reaching insight to the meaning, important and the development of the marine or blue economy concepts and their relationship with goal 14 of the 2019 UN sustainable development goals. Because of the importance of Deodat Maharaj views captured in the forward to the said paper, it is offered to quote in extenso as follows:
"2.2 billion citizens, many of whose livelihoods and food security depend upon the world's oceans, seas and coastal areas - the largest ecosystem on the planet. In the years following the 2012 Rio Summit, we have witnessed a marked increase in international awareness of the oceans' potential as a key driver of sustainable economic growth. This contribution was subsequently ratified by the international community's adoption of the Sustainable Development Goals in September 2015. Goal 14 specifically recognises the critical contribution the ocean can make to the development of the smallest and most vulnerable nations. Furthermore, the emergence of the 'blue economy' concept demonstrates a set of practical strategies to ensure that economic activities do not compromise the long-term capacity of ocean ecosystems to support those activities, and remain resilient and healthy. Managing the oceans effectively is a uniquely cross- national, cross-sectoral challenge. With its cross-cutting nature, the blue economy concept offers a unique opportunity to address complex and inter-connected challenges, without compromising economic growth". ${ }^{4}$

Adumbrating further on the blue economy concept and the need for its implementation to meeting the broad range of sustainable development outcomes, given its great potentials the forward to the Commonwealth Blue Economy paper referred above, further stated as follows:

"This is a concept that, if implemented effectively, can contribute to a significantly broad range of sustainable development outcomes. It has the potential to help countries to make the transition from their current trajectories of over consumption to more resource-efficient societies that rely more strongly on renewable marine resources to satisfy consumers' needs and industry demand, and to tackle climate change. The Commonwealth has a long history of engagement on issues relating to ocean management and sustainability and, for a number of years, has advocated and promoted the blue economy concept as a holistic means of addressing sustainable development at multiple levels. Indeed, long before the Rio Summit in 2012, Commonwealth Heads of Government had stressed the need for practical outcomes on the blue economy to ensure the sustainable management of oceans as the basis for livelihoods, food security and economic development. Furthermore, most recently, at their meeting in Malta in November 2015, Commonwealth Heads of Government fully acknowledged that the development of a sustainably managed blue economy would offer significant opportunities for economic growth and general development for many Commonwealth states. In order to fully realise the many opportunities presented by pursuing a blue economy approach, fundamental changes are required to address the matter of ocean governance at the national, regional and global levels. If we are going to create ocean solutions that are sustainable over the long term, we need to recognise the interdependencies of the three dimensions of sustainable development, which must be mutually reinforcing. Fundamentally, existing sectors must be managed in a much more sustainable manner. Small and developing states must also embrace the development of new sectors, many of which have a strong technology base, to achieve more diversified and resilient economies. Such change can only be realised through strong leadership. Nowhere is this truer than for the ocean, a resource perceived to be everyone's right but no one's responsibility. Creating the political will to implement all elements of a blue economy strategy is a key theme in the assistance and advice the Commonwealth provides to countries. It is our belief that much of the focus and

\footnotetext{
${ }^{1}$ Blue Economy Summit scheduled to be held from the 19th to the 20th of January 2014 in Abu Dhabi, United Arab Emirates on the sidelines of the Abu Dhabi Sustainability Week: https://sustainabledevelopment.un.org/content/documents/2993BEprogramme.pdf, Blue Economy Concept Paper: https://sustainabledevelopment.un.org/content/documents/2978BEconcept.pdf, see also Draft Abu Dhabi Declaration Blue Economy: https://sustainabledevelopment.un.org/content/documents/2983BEdeclaration.pdf, Logistical Note: Blue Economy Summit: https://sustainabledevelopment.un.org/content/documents/2988BElogistics.pdf,

${ }^{2}$ The Blue Economy and Small States Commonwealth Blue Economy Series, No. 1, https://www.thecommonwealthilibrary.org/commonwealth/industry-and-services/commonwealth-blue-economy-series_25191349

${ }^{3}$ Ibid.

${ }^{4}$ The blue economy Growth, opportunity and a sustainable ocean economy: An Economist Intelligence Unit briefing paper for the World Ocean Summit 2015, see page of the 7 report at https://www.oceanprosperityroadmap.org/wpcontent/uploads/2015/05/2.-State-of-the-Blue-Economy briefing-paper_WOS2015.pdf visited on the 21/04/2020.
} 
emphasis must be placed on governance in order to successfully transition to a vibrant blue economy. The Commonwealth has a niche and is a global leader in supporting countries to effect the necessary changes. This Commonwealth Blue Economy Series presents a synthesis of information and practical advice to Commonwealth governments relating to the potential deployment of a range of policy options for different sectors and opportunities for the road ahead. In so doing, this series aims to support the development of the blue economy in Commonwealth countries by providing a high-level assessment of the opportunities available for economic diversification and sustainable growth". ${ }^{1}$

Flowing from the above the marine or blue economy can be viewed broadly to include economic activities which directly or indirectly use the sea as an input. It is worthy of note also that the India's Economic Intelligence Unit has also adopted a working definition of the blue economy to mean: "a sustainable ocean economy which emerges when economic activity is in balance with the long-term capacity of ocean ecosystems to support this activity and remain resilient and healthy". ${ }^{2}$

Closely related to the above to the World Wildlife Fund (WWF) ${ }^{3}$, Living Blue Planet Report 2015 has also established that "nearly 3 billion people rely on fish as a major source of protein and $10-12$ percent of the world's population depends on it for livelihood. The ocean generates economic benefits worth at least USD 2.5 trillion per year. However, unchecked exploitation of the ocean habitat and species by human intervention has brought the oceans to the brink of collapse. Marine vertebrate population has declined 49 percent between 1970 and 2012 ". It has also been established that "a number of fish species utilized by humans too has fallen by half. Around one in four species of sharks, rays and skates is now threatened with extinction due to overfishing. Tropical reefs have lost more than half their reef-building corals over the last 30 years and nearly 20 percent of mangrove cover was lost between 1980 and 2005. More than 5 trillion plastic pieces weighing over 250, 000 tons are in the sea and oxygen-depleted dead zones are growing as a result of nutrient run-off'. ${ }^{5}$ Before considering the threats to the actualization of goal 14 of the $219 \mathrm{UN}$ sustainable development goals, it is now offered to examine in summary the life below water in rivers, coasts and seas in Nigeria as follows:

\section{An Overview of Life below Water in the Rivers, Coasts and Seas in Nigeria:}

According to Prof. Amari Omaka in his book titled "Fundamentals of Maritime Admiralty and International Water Law"

"freshwater ecosystems and wetlands are some of the most productive ecosystems which are essential in the provision of environmental goods and services. Gladly, Nigeria is well-endowed with freshwater and wetland ecosystems (lakes, rivers and wetlands) covering about 13 million hectares of the geographical territory. The country is largely drained by four major basin system including (i) the Niger River basin drainage system with its major tributaries of Benue, SokotoRima, Kaduna, Gongola, Katsina - Ala, Donga, Taraba, Hawal and Anambra; (ii) the Lake Chad inland drainage system comprising Kano, Hadejia, Jama' are, Misau, Komadougou- Yobe, Yedseram and Ebeji Rivers; (iii) the Atlantic drainage system to the west of the Niger consisting of the Ogun, Oshun, Benin, and Owena Rivers; (iv) the Atlantic drainage system to the east of the Niger made up of the Anambra, Imo, Cross, Qua Iboe and Kwa Rivers. In addition, three major types of groundwater aquifers are observed in the country, namely: basement aquifers, deep coastal sedimentary aquifers and superficial aquifers. The total quantity of Nigeria's annual groundwater recharge is estimated at about 9.5 trillion litres. Numerous lakes and wetlands also exist in the country including Lake Chad that is shared with Chad, Cameroun and Niger Republics as well as wetlands of international importance which are seasonal habitats for Palearctic migrants". 6

\footnotetext{
${ }^{1}$ Ibid.

2

3 Living Blue Planet Report: Species, habitats and human well-being: https://wwf.panda.org/wwf_news/?252590/living-blue-planet-report https://assets.wwf.org.uk/downloads/living_blue planet_report_2015.pdf, also see http://ocean.panda.org/

${ }^{4}$ Ibid.

${ }^{5}$ Ibid.

${ }^{6}$ See Amari Omaka, (SAN), Professor of Law and Senior Advocate of Nigeria: Fundamentals of Maritime, Admiralty and International Water Law, first published: 2018, published \& printed by: Princeton \& Associates Publishing Co. Ltd., 9, Ezekiel Street, Off Toyin Street, Ikeja, Lagos. Page .
} 
It is a moot point in Nigeria that its marine and coastal environment is about $853 \mathrm{~km}$ along the coastline and inland measuring a distance of around $15 \mathrm{~km}$ in Lagos towards the west and around about $150 \mathrm{~km}$ in the Niger Delta and $25 \mathrm{~km}$ of the east of the region of the Niger Delta. The environmental architecture is made of the "barrier bar/lagoon system, the Mahin mud coast, the Niger Delta, Strand coast and a moderately wide continental shelf". ${ }^{1}$ It is proposed now to examine the potential threats to the actualization of goal 14 of the 2019 UN sustainable development goals.

Existing Potential Threats and Legal Framework to the Actualization of Goal 14 of United Nations 2019 Sustainable Developments Goal

\section{Threats to the Ocean Acidification:}

Ocean acidification means that the chemical composition of the water in the ocean is changing over time (otherwise known as the $\mathrm{PH}$ ). Recent studies have shown that the $\mathrm{PH}$ of the global waters in the coasts and oceans are decreasing and that the water is becoming more acidic. ${ }^{2}$ That is why it has been appropriately stated that:

"Ocean acidification is caused mainly by the uptake of carbon dioxide $\left(\mathrm{CO}_{2}\right)$ from the atmosphere, the ocean absorbs about 30\% of the $\mathrm{CO}_{2}$ in the atmosphere, this happens wherever air meets the water. $\mathrm{CO}_{2}$ emissions above water are increasing from human activity, such as burning fossil fuels, resulting in an increased amount of $\mathrm{CO}_{2}$ getting into the ocean. Once in the ocean the $\mathrm{CO}_{2}$ changes the chemical make-up of the water $\left(\mathrm{H}_{2} \mathrm{O}\right)$. This results in the water becoming more acidic, this is carbonic acid. The increased acidity of the seas and ocean can cause major problems for marine organisms and ecosystems. Many sea creatures are affected by acidification, for example it can prevent the building of shells or the formation of corals. It can even alter the feeding patterns of some fish. It can have a dramatic effect on the whole marine eco-system ". ${ }^{3}$

The potential threats and the dangers of acidification, though oftentimes undermined, has nevertheless, been reinforced succinctly as follows:

"one of the most serious human-caused threats to endanger our ocean; a threat that, like climate change, is a result of ongoing burning of fossil fuels and emissions from land-use changes. As the carbon dioxide (CO2) level in the atmosphere rises, an increasing amount of the gas is absorbed by the ocean, causing a profound change in its chemistry by making it more acidic". ${ }^{4}$

Unfortunately, however, the global community appears yet totally unprepared to deal with the scourge of ocean acidification as: "existing treaties appear ill-equipped to address the ever growing problem of ocean acidification". 5 "To date, ocean acidification has not been explicitly included in the mandate of any international treaty, including the United Nations Convention on the Law of the Sea (UNCLOS), the United Nations Framework Convention on Climate Change (UNFCCC) or the Convention on Biological Diversity (CBD)". ${ }^{6}$

It is gratifying to note, however that, "both the academic challenge as well as the practical urgency to find solutions to ocean acidification within the broader field of environmental law and governance has spurred some initial analysis on this topic". ${ }^{7}$ Several international agreements and institutions have, also begun to address it in various ways and has being primarily included in general calls for concern, and considered through the scientific arms of various conventions and frameworks ${ }^{8}$. Furthermore, the recent report of the International Union for Conservation of Nature (IUCN) has brought some hope as it has examined international policy and governance options and presently contributes "to the growing literature and discussion concerned with the performance and transformational need of ocean governance and policies and the need to fully incorporate ocean acidification into

\footnotetext{
${ }^{1}$ Ibid.

${ }^{2}$ http://oceans.digitalexplorer.com/resources/?controller=search, Video from the Alliance for Climate Education (3:01) https://www.youtube.com/watch?v=Wo-bHt1bOsw, National Geographic: http:/ocean.nationalgeographic.com/ocean/critical-issues-ocean-acidification// Smithsonian Museum: http://ocean.si.edu/ocean-acidification ${ }^{3}$ Ibid.

4 See https://www.iucn.org/content/iucn-releases-new-guidance-document-ocean-acidification-policy-and-governanceoptions, visited on 26 day of August, 2020.

${ }^{5}$ Ibid.

${ }^{6}$ Ibid.

${ }^{7}$ Ibid.

${ }^{8}$ Ibid.
} 
other pertinent environmental, social and economic deliberations towards a sustainable, low-carbon society".$^{1}$ The said report has succeeded in "outlining major policy gaps and avenues that can help to remedy the existing deficiencies on the current policy governance of ocean acidification at the global level". ${ }^{2}$ It is submitted that the current tempo and momentum be maintained to save the oceans of the world from further acidification. It is further submitted that: "sustained reflections on how to strengthen and better inter-link between existing international instruments" 3 and possible ways forward should, now be vigorously pursued by the global community.

\section{Threats to Ocean Dead Zones:}

A Dead Zone been defined as: "an area of the sea that has very little marine life. They can occur naturally, but the real issue is when they occur as a result of human activity" . Research findings have established that "Dead Zones are areas with low-oxygen, sometimes called hypoxic, it is difficult for plants or animals to survive in these conditions". Several factors have been fingered as the causes of a dead zone in oceans though "nutrient pollution has been identified as one of the main human activities causing the problem."6 Other causes includes the increased use of excess fertilizer by farmers in the process of crop production and whenever there is a run off of the lands, where crop cultivation is taking place in the land into to the sea. "The ocean can end up with excess nutrients leading to a process called eutrophication. This can encourage the growth of algae that can block sunlight from reaching the water. When the algae in the ocean dies it decomposes". ${ }^{7}$ The further consequences is that the water oxygen is used up making a difficulty of animals and plants in the sea in such areas to survive. In these Dead Zones it is usually hard for any marine life to survive. "This can have a wide effect as it can disrupt food chains leaving some marine mammals without food". "They can also result in the introduction of harmful chemicals into the food chain". 9

According to the United States Environmental Protection Agency (EPA): ${ }^{10}$

"Dead zones are areas of water bodies where aquatic life cannot survive because of low oxygen levels. Dead zones are generally caused by significant nutrient pollution, and are primarily a problem for bays, lakes and coastal waters since they receive excess nutrients from upstream sources". ${ }^{11}$

The causes, life span, negative effects on aquatic life of ocean dead zones have also been traced to "excess nitrogen and phosphorus --- an overgrowth of algae in a short period of time. "This is also called algae blooms. The overgrowth of algae consumes oxygen and blocks sunlight from underwater plants. When the algae eventually dies, the oxygen in the water is consumed". ${ }^{12}$ The lack of oxygen makes it impossible for aquatic life to survive. The largest dead zone in the United States - about 6,500 square miles - is in the Gulf of Mexico and occurs every summer as a result of nutrient pollution from the Mississippi River Basin". ${ }^{13}$ There are different types of algae on seas, lakes, reservoirs, rivers, ponds, bays and coastal waters but almost all types are harmful to the environment as follows:

"When some types of algae blooms are large and produce chemicals, or toxins, the event is called a harmful algal bloom. Harmful algal blooms can occur in lakes, reservoirs, rivers, ponds, bays and coastal waters, and the toxins they produce can be harmful to human health and aquatic life.

\footnotetext{
${ }^{1}$ Ibid.

${ }^{2}$ Ibid.

${ }^{3}$ Ibid.

$4 \quad$ http://www.bbc.co.uk/schools/gcsebitesize/science/edexcel, http://oceanservice.noaa.gov/facts/deadzone.html, http://education.nationalgeographic.com/encyclopedia/dead-zone/, ${ }^{5}$ Ibid.

${ }^{6}$ Ibid.

${ }^{7}$ Ibid.

${ }^{8}$ Ibid.

${ }^{9}$ Ibid.

${ }^{10} \mathrm{https}$ ://www.epa.gov/nutrientpollution/effects-dead-zones-and-harmful-algal-blooms

${ }_{11}^{1}$ Ibid.

${ }^{12}$ Ibid.

${ }^{13}$ Ibid.
} National

Ocean Service: http://www.teachoceanscience.net/teaching resources/education_modules/dead zones/learn_about/ 
Harmful algal blooms are mainly the result of a type of algae called cyanobacteria, also known as blue-green algae". ${ }^{\prime}$

It has also been established that "elevated nutrient levels and algal blooms can also cause problems in drinking water in communities nearby and upstream from dead zones. Harmful algal blooms release toxins that contaminate drinking water, causing illnesses for animals and humans". ${ }^{2}$

In Nigeria, prior to the establishment of the Federal Environmental Protection Agency in 1988, effective industrial and legal frameworks for environmental degradation and pollution control was lacking. This decree gave the agency the overall responsibility of environmental protection and environmental management in Nigeria. ${ }^{3}$ However, the NESREA Act 2007, consolidated on the gains of the FEPA Act. Consequently, Section 23 and 24 provide National Environmental Standards for Water Quality in Nigeria, which was lacking in previous legislation. Section 23 provides that the agency shall make recommendations on water standards for protection of marine life, public water supplies, agriculture and industrial uses. The potency or effectiveness of the above Act in dealing with the environmental issues mentioned above, however, is doubtful. We shall now examined threats of ocean overfishing and wastes in the oceans.

\section{Threats to Ocean Overfishing:}

Overfishing occurs when we remove fish too quickly or in too large quantities from oceans (or rivers) "when we are catching more fish than can naturally replenish (keep fish numbers at the same levels), overfishing happens. It is an unsustainable use of the ocean for fishing". "A number of factors contribute to the overfishing of the ocean, including the development of fishing technology and the growing appetite for certain types of fish. As populations increase, the need for food increases. People are also increasing their demand for varieties and amount of fish. Fisheries are meeting this growing demand and are able to increase their profits from using methods that result in a bigger and faster catch. Unsustainable practices: several practices have being isolated has been responsible for causing overfishing. These include: "blast fishing (the practice of using dynamite to kill schools of fish to maximise a catch), bottom trawling (using a heavy net to trawl along the ocean floor, damaging habitats) and by-catch (modern fishing nets can bring up unwanted fish or mammals with the catch, which then die and are discarded overboard)". Also there are "too many fishing fleets for the amount of fish available. It is estimated that there are four times the amount of fishing boats needed for our planet. Some species will become extinct if we continue to catch them in such high quantities, e.g. Bluefin tuna". ${ }^{5}$ Over fishing is also known to destroy ecosystems: Some of the less targeted fishing methods, such as blast fishing, can result in the destruction of whole areas of marine habitats. Additionally, reducing the numbers of specific species can change food chains, which can have destructive results across the ecosystem. The instruments for curbing overfishing at the international level is widely covered under the United Nations Convention on the Law of the Sea. ${ }^{6}$

In Nigeria, the Nigerian Fishes Act 1971, ${ }^{7}$ operates to prohibit the "navigation of any fishing boat within Nigerian territorial waters unless a license has been issued to the owner thereof. It is also an offence to take or kill any fish in any water in the Nigerian with poison or explosives. Contraveners shall pay a fine of $\$ 200.00$ or face six months jail term". This law is clearly now archaic and out of turn with current realities given the fact that the law was enacted since 1971 and the penalty fixed at the time, that is $\$ 200.00$ which has little of no value in Nigeria at the moment. This amount at present cannot even buy a big loaf of bread in Nigeria. A potential contravener can easily pay the sum of $\$ 200.00$ than going to jail. This law, is therefore recommended for immediate review to tally with the realities of our current age.

\footnotetext{
${ }^{1}$ Ibid.

${ }^{2}$ Ibid.

${ }^{3}$ Section 4 of the NESREA Act 2007.

4 http://thecaudallure.blogspot.co.uk/2011/07/genetic-diversity-losing-out-to.html, World Wildlife Fund: https://www.worldwildlife.org/threats/overfishing, National Geographic http://ocean.nationalgeographic.com/ocean/critical-issues-overfishing/, $\quad$ UN http://www.un.org/events/tenstories/06/story.asp?storyID $=800$

${ }^{5}$ Ibid.

${ }^{6}$ For further discussion see: https://www.nationalgeographic.com/news/2017/12/un-high-seas-conservation-treaty-oceanprotection-spd/ https://scholarship.law.unc.edu/cgi/viewcontent.cgi?referer=https://www.google.com/\&httpsredir=1\&article=1671\&context= ncilj

${ }^{7}$ Act No. 30 of $10^{\text {th }}$ June, 1971
} 


\section{Threats of Wastes in the Ocean:}

It is estimated that 8 million tonnes of plastic waste end up in the ocean every year. Jenna Jambeck, at the University of Georgia, says "it is like having five shopping bags of trash on every foot of coastline around the globe. Plastic is one of the main waste products that end up in the sea, although marine waste can include anything from glass to cans to abandoned sailing boats. Many of the objects in the ocean end up in giant 'garbage patches.' These are massive areas where waste gathers, that are formed by ocean currents". ${ }^{1}$ Five major well known sources of wastes in the oceans (also known as garbage patches) are: "two in the Pacific Ocean, two in the Atlantic Ocean and one in the Indian Ocean. The Great Pacific Garbage Patch is estimated to be larger than the state of Texas, but currently no-one has a really accurate way of measuring it". ${ }^{2}$ There are various reasons adduced has been responsible for wastes in the world's oceans. They include (1) wastes intentionally dumped by human beings or corporate entities, (2) wastes that are dropped carelessly on lands which nevertheless find there ways into the oceans, (3) wastes originating from natural disasters: including tsunami and hurricane wastes, (4) recent unconfirmed reports in the social media showing that dead victims from the ravaging Covid-19 pandemic are now being thrown into the rivers, seas or oceans by certain sections of the global communities. One hopes that these reports are not true because the effect of such development will negatively affect the life below water. Ocean wastes are known to negatively affect marine life in many ways. This can happen in the undermentioned ways:

- "Birds, fish and other sea creatures can become trapped in plastic bags, netting or packaging and may get injured or die.

- Marine mammals and birds can end up swallowing waste in the water. It has been well documented that turtles, for example, mistake plastic bags for jellyfish. Eating waste can lead to illness or starvation.

- Some of the marine debris is made up of material that contains chemicals that are harmful to fish and other species. Whilst this may not directly harm the sea life that swallows the waste, it can result in harmful toxins entering the food chain". 3

The Convention dealing with prevention of marine pollution via the dumping of wastes and other matter ${ }^{4}$ remains the Convention on the Prevention of Marine Pollution by Dumping of Wastes and Other Matter 1972, also known as "the London Convention". This Convention is reputed has the first convention around the globe directed at protecting the marine environment from the activities of humanity. It has been in operation since the year 1975. Its major objective is "to promote the effective control of all sources of marine pollution and to take all practicable steps to prevent pollution of the sea by dumping of wastes and other matter. Currently, 87 States are Parties to this Convention". 5 It remains to be added that "in 1996, the "London Protocol" was agreed to further modernize the Convention and, eventually, replaced it. Under the Protocol all dumping is prohibited, except for possibly acceptable wastes on the so-called "reverse list". The Protocol entered into force on 24 March 2006 and there are currently 53 Parties to the Protocol". 6

The position of dumping of wastes in Nigerian coasts is governed by the Harmful Wastes (Special Criminal Provisions) Act, $2004^{7}$. Under this head, this paper reproduces what the lead author this paper has said in his $\mathrm{Ph} . \mathrm{D}$ thesis (unpublished) as follows:

"A major statute enacted to protect the Nigerian environmental generally and also purports to protect the Niger Delta Region, in particular, is Harmful Wastes (Special Criminal Provisions) Act. This Act was originally promulgated in the year 1988 in swift response to the dumping of toxic substances by an Italian company acting in concert with Nigerian businessmen at Koko Town in Delta State in the Niger Delta of Nigeria. It is on record that Nigerian's environmental protection policy and laws were barely existing and visibly prostrate until this deadly development. It was therefore the above development that jolted

1 Adapted from National Geographic, Greenpeace: http://www.greenpeace.org/international/en/campaigns/oceans/fit-for-the-future/pollution/trash-vortex/, National Geographic: http:/education.nationalgeographic.co.uk/encyclopedia/great-pacific-garbage-patch/, Eco Kids: http://www.ecokids.ca/pub/eco info/topics/oceans/risks to oceans.cfm

${ }^{2}$ Ibid.

${ }^{3}$ Ibid.

${ }^{4}$ http://www.imo.org/en/OurWosrk/Environment/LCLP/Pages/default.aspx

${ }^{5}$ Ibid.

${ }^{6}$ Ibid. See also IMODOCS website, at http://docs.imo.org. An extensive compilation of the events leading up to the adoption of the Convention and Protocol, as well as many of the historical documents (meeting reports, etc.), is available on the IMO Maritime Knowledge Centre website.

${ }^{7}$ Originally enacted via Supplement to Official Gazette Extraordinary no.79. Vol.75A. 779 
the Federal Government to promulgate the Harmful Wastes (Special Criminal Provisions) Act Cap 165 and also the Federal Environment Protection Agency Act (FEPA). It is also on record that it was the Koko incident that aroused global concerns which led to the Basel Convention on the control of Transboundary Movements of Hazardous Waste and their disposal and the Bamako Convention on the Ban of the Import into Africa and the Control of Transboundary Movement of Hazardous Wastes within Africa. The latter was adopted by the Organization of African Unity (now African Union) member states following their concern that the Basel Convention did not include a total ban". ${ }^{\prime}$

\section{CONCLUSION:}

This paper has attempted to analyze goal 14 (life below water/targets) of the United Nations' sustainable development goals 2019 to the development of marine/ blue economy towards the attainment of the said goal, existing legal framework and potential threats in Nigeria and the global environment. The threats examined in this paper included: the threat of ocean acidification, the threat of ocean dead zones, the threat of overfishing and the threat of ocean waste in the oceans and the various existing international and domestic statutes, treaties and conventions. The paper is of the view that much still needs to be done to actualize targets set under goal 14 of the United Nations' sustainable development goals 2019. The following recommendations drawn from the above analyses are hereby made.

\section{RECOMMENDATIONS:}

1. It is submitted that humanity should use fewer plastic products. This is because plastics that end up as ocean debris contribute to habitat destruction and entangle and kill tens of thousands of marine animals each year. To limit the negative impact, nations of the world should encourage people from dropping or littering plastics, carry reusable water bottles, learn to store food in containers that are non-disposable and institutionalized the recycling of generated wastes, whenever possible.

2. It is also suggested that rivers floodplains be regularly maintained by government around the nations of the world.

3. Nations should maintain flat areas of land next to rivers to reduce leaves and mud from flowing into rivers and from there into the oceans.

4. Farm and sewage wastes effectively managed to stop sediments from entering rivers and oceans.

5. It is also submitted that humanity make Safe, sustainable seafood choices globally since global fish populations are rapidly being depleted due to demand, loss of habitat, and unsustainable fishing practices especially in the face of reports in the social media showing that dead victims from the ravaging Covid-19 pandemic are now being thrown into the rivers, seas or oceans by certain sections of the global communities.

6. "Given future climate change predictions, and with some $40 \%$ of the world's population living on the coast and billions of dollars' worth of infrastructure situated in coastal cities (with further substantive investment expected over the next decade), the ingredients are in place for significant economic damages if we continue to degrade our natural coastal defences". ${ }^{2}$

7. "The costs of taking action largely are offset by the long-term gains. In economic terms, the Convention on Biological Diversity suggests that world scales up actions to sustain the global ocean requirement of a US\$32 billion one-time public cost and US\$21 billion dollars a year for recurring costs". ${ }^{3}$

8. For open ocean and deep sea areas, sustainability can be achieved only through increased international cooperation to protect vulnerable habitats. Establishing comprehensive, effective and equitably managed systems of government-protected areas should be pursued to conserve biodiversity and ensure a sustainable future for the fishing industry.

9. On a local level, we should make ocean-friendly choices when buying products or eating food derived from oceans and consume only what we need. Selecting certified products is a good place to start.

10. Nations should eliminate plastic usage as much as possible and organize beach clean-ups.

11. Nations should increase the sensitization of the global community about the importance of marine life and the need to protect it.

\footnotetext{
${ }^{1}$ See also Ekpu A.O.O. op cit p.90

${ }^{2}$ See footnote 27 and 29 above.

${ }^{3}$ Ibid.
} 
12. Nations of the world should take urgent steps to protect and improve the coastal and marine ecosystems through the introduction of a comprehensive ecological master plan which must include baseline data of freshwater and wetland ecosystems. 